Gut, 1969, 10, 71-73

\title{
Reduction of gastric acid secretion on a low-salt diet and furosemide
}

\author{
M. L. KOTHARI ${ }^{1}$, J. C. DOSHI, H. G. DESAI, A. B. VAIDYA, \\ U. K. SHETH, AND J. M. MEHTA \\ From the Department of Clinical Pharmacology, Seth G.S. Medical College, the Department of \\ Medicine, K.E.M. Hospital, and the Department of Gastroenterology, Bai Yamunabai L. Nair \\ Charitable Hospital, Bombay, India
}

The management of peptic ulcer essentially consists of the neutralization or the reduction of gastric hydrochloric acid $(\mathrm{HCl})$ by the use of antacids, anticholinergics, or by surgery. The drugs are partially effective, and surgery, with its known hazards, has a limited application. Johnston (1965), in a review of the various medical methods for the reduction of gastric acid secretion, concluded that none was satisfactory. An accidental observation of the relief of symptoms of duodenal ulcer in a patient while on a low-salt diet, advised for a different reason, prompted the present study.

\section{MATERIAL AND METHODS}

Twelve patients with active duodenal ulcer and six healthy controls, a total of 18 subjects, were studied. Seventeen were males and one female. The gastric secretory response was studied either by the augmented histamine test (AHT) (Kay, 1953) or by the histamine infusion test (HIT) (Lawrie, Smith, and Forrest, 1964; Desai, Borkar, and Jeejeebhoy, 1967). In overnight fasting subjects, a 14 to 16 French Levine tube was passed under fluoroscopic control along the greater curvature of the stomach with the tip of the tube placed at the right border of the vertebral column. The patients were ${ }^{1}$ Please address requests for reprints to Dr Kothari, at the Department of Clinical Pharmacology, Seth G.S. Medical College, Parel, Bombay 12 instructed to lie on the left side and not to swallow saliva during the period of collection. The gastric secretion was collected by intermittent hand suction. After aspirating the fasting contents, $50 \mathrm{mg}$ mepyramine maleate was injected intramuscularly and the basal secretion collected for half an hour. Histamine acid phosphate was then injected subcutaneously (AHT) or given in an infusion of $5 \%$ glucose (HIT). In the AHT the collection of gastric secretion was done for one hour after the injection of histamine. In the HIT, four 15-minute samples were collected after a 'steady state' was reached and pooled. The total acidity in the gastric samples was titrated against freshly prepared $\mathrm{N} / 10 \mathrm{NaOH}$ using phenolpthalein as the indicator and expressed as m-equivalents per hour of $\mathrm{HCl}$ (Lawrie and Forrest, 1965; Desai et al, 1967).

In the first group of seven subjects (Table I), the acid output was measured, on admission, by the AHT (histamine $0.04 \mathrm{mg} / \mathrm{kg}$ body weight). The test was repeated after a period of nine to 20 weeks (mean period $=14$ weeks) on a low-salt diet. A low-salt diet meant the avoidance of common salt $(\mathrm{NaCl})$ in food. No other dietary restrictions were imposed and no drugs prescribed. In subject no. 1 (control), the acid output was measured on six occasions, before and after maintenance on a low-salt diet, with an interval of 15 days between two successive tests. In the second group of 11 subjects, the $\mathrm{HCl}$ output was measured, on admission, by the HIT (histamine $0.04 \mathrm{mg} / \mathrm{kg}$ body weight/hour in subjects weighing more than $50 \mathrm{~kg}$ and a dose of $2.0 \mathrm{mg} /$ hour in

TABLE I

GASTRIC ACID OUTPUT (AHT) BEFORE AND AFTER LOW-SALT DIET

\begin{tabular}{|c|c|c|c|c|c|}
\hline \multirow[t]{2}{*}{ No. } & \multirow[t]{2}{*}{$\operatorname{Age}(y r)$} & \multirow[t]{2}{*}{ Subject } & \multicolumn{3}{|c|}{$\mathrm{HCl}(\mathrm{m}$-equiv/hr) } \\
\hline & & & On Admission & After Salt Depletion & Difference \\
\hline $\begin{array}{l}1 \\
2 \\
3 \\
4 \\
5 \\
6 \\
7\end{array}$ & $\begin{array}{l}30 \\
24 \\
36 \\
40 \\
50 \\
54 \\
54\end{array}$ & $\begin{array}{l}\text { Control } \\
\text { Duodenal ulcer } \\
\text { Duodenal ulcer } \\
\text { Duodenal ulcer } \\
\text { Duodenal ulcer } \\
\text { Duodenal ulcer } \\
\text { Duodenal ulcer }\end{array}$ & $\begin{array}{l}43 \cdot 81^{1} \\
53 \cdot 0 \\
28 \cdot 4 \\
36 \cdot 9 \\
41 \cdot 8 \\
29 \cdot 8 \\
17 \cdot 41\end{array}$ & $\begin{array}{l}27 \cdot 7^{1} \\
21 \cdot 2 \\
22 \cdot 8 \\
33 \cdot 5 \\
18 \cdot 7 \\
24 \cdot 6 \\
15 \cdot 41\end{array}$ & $\begin{array}{l}-16 \cdot 1 \\
-31 \cdot 8 \\
-5 \cdot 6 \\
-3 \cdot 4 \\
-23 \cdot 1 \\
-5 \cdot 2 \\
-2 \cdot 0\end{array}$ \\
\hline
\end{tabular}

t- 2.870 df $=6 \quad P<0$.

All subjects were males. 
TABLE II

GASTRIC ACID OUTPUT (HIT) BEFORE AND AFTER FUROSEMIDE

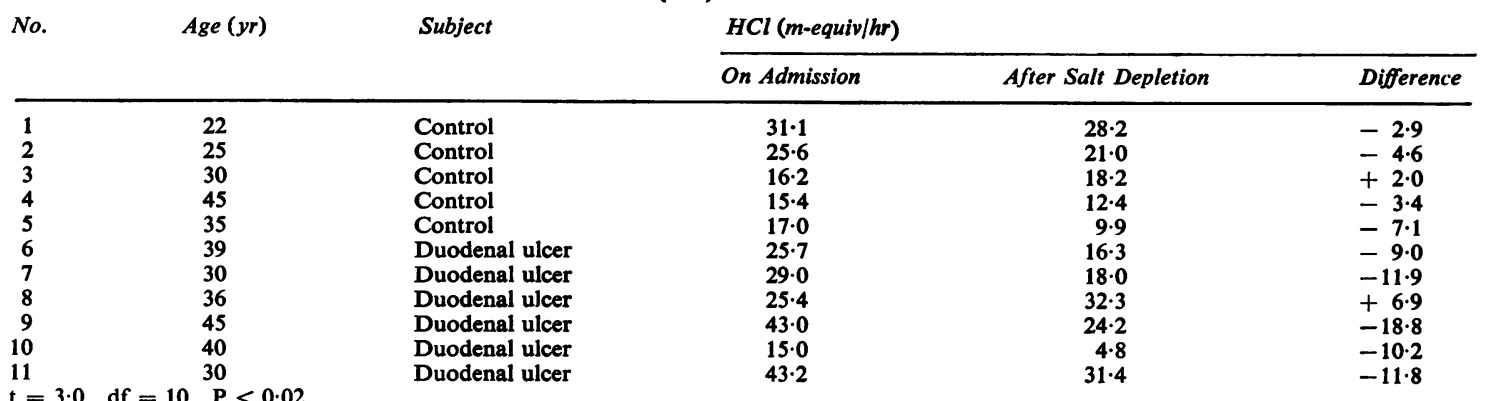

TABLE III

GASTRIC ACID OUTPUT IN SIX SERIAL TESTS (AHT) BEFORE AND AFTER SALT DEPLETION IN CASE 1

No.

$\mathrm{HCl}($ m-equiv/hr)

\begin{tabular}{lcc} 
& On Admission & After Salt Depletion \\
\hline 1 & $43 \cdot 0$ & $28 \cdot 4$ \\
2 & $43 \cdot 8$ & $28 \cdot 0$ \\
3 & $44 \cdot 1$ & 26.9 \\
4 & $44 \cdot 3$ & $27 \cdot 3$ \\
5 & $43 \cdot 4$ & $28 \cdot 2$ \\
6 & $44 \cdot 2$ & $27 \cdot 4$ \\
Average & $43 \cdot 81$ & $27 \cdot 7$
\end{tabular}

those weighing less than $50 \mathrm{~kg}$ ). Thereafter, furosemide was administered orally in the dosage of $40 \mathrm{mg}$ twice daily for a period of 10 days. The subjects were on a lowsalt diet during the same period. Sixteen to 24 hours after the last dose of furosemide, the HIT was repeated.

\section{RESULTS}

Table I shows the $\mathrm{HCl}$ output on histamine stimulation (AHT) before and after a low-salt diet. All the seven subjects showed a significant fall in output of $\mathrm{HCl}(\mathrm{P}<0.05)$. Table II shows the $\mathrm{HCl}$ output (HIT) before and after furosemide. Nine of the 11 subjects showed a significant fall in the acid output $(P<0.02)$. In subjects in whom the tests were repeated in order to judge the reproducibility of the results, the mean and SD of the differences of acid output in two tests were $0.11 \pm 0.98 \mathrm{~m}$-equiv/ $\mathrm{hr}$ on AHT and $1.1 \pm 0.56 \mathrm{~m}$-equiv/hr on HIT (Desai et al, 1967).

\section{DISCUSSION}

A significant reduction in the gastric acid output was observed with a low-salt diet alone and in combination with furosemide in 16 out of 18 subjects. This observation may provide a new approach in the management of peptic ulcer.
Taylor (1955) has mentioned that many years ago Kahn produced acid-free gastric juice in animals by prolonged feeding with chloride-free meat. Lahiri (1953) showed a fall in gastric $\mathrm{HCl}$ output on a low-salt diet. The possible mechanisms underlying the reduction of $\mathrm{HCl}$ secretion, observed in the present study, may be as follows:

1 The formation of $\mathrm{HCl}$ by the parietal cells involves the following reaction (Hightower, 1966):

$$
\mathrm{NaCl}+\mathrm{H}_{2} \mathrm{O}+\mathrm{CO}_{2} \rightleftharpoons \mathrm{HCl}+\mathrm{NaHCO}_{3}
$$

According to the law of mass action, the reduction in the availability of $\mathrm{NaCl}$, one of the reacting masses, can decrease the speed of forward reaction and hence diminish $\mathrm{HCl}$ production. A significant rise in basal $\mathrm{HCl}$ secretion has been observed in man after intravenous infusions of normal saline (Barreras and Donaldson, 1967). This shows that an increase in the availability of $\mathrm{NaCl}$, the ultimate source of the chloride ion for $\mathrm{HCl}$ formation (Hightower, 1966), can step up the speed of the reaction and increase the production of $\mathrm{HCl}$.

2 Salt withdrawal has been shown to increase the circulating levels of aldosterone in man (Leutscher and Axelrad, 1954; Crabbé, Reddy, Ross, and Thorn, 1958; Bledsoe, Island, and Liddle, 1966) and animals (Binnion, Davis, Brown, and Olichney, 1965; Cade and Perenich, 1965). This may act at the level of the parietal cell, altering the rates of ionic transfer and thus depress the formation of HCl. Van Buchem, Doorenbos, and Elings (1956) observed histamine-fast achlorhydria in a patient with primary aldosteronism (Conn's syndrome). Following the removal of the tumour, the patient showed a very high level of $\mathrm{HCl}$ secreted.

Inhibition of carbonic anhydrase has been postulated as a mechanism for the reduction of $\mathrm{HCl}$ secretion by the stomach on the administration of diuretics such as acetazolamide or chlorothiazide in man (Kramer and Markarian, 1959; Lindner, 
Cohen, Dreiling, and Janowitz, 1962) and animals (Ojha and Ahmed, 1967). In the present study, the last dose of furosemide was administered orally 16 to 24 hours before the HIT, by which time it is known to lose its activity (Robson, Kerr, Aschcroft, and Teasdale, 1964). Moreover, furosemide has been shown to have no effect on carbonic anhydrase (Muschaweck and Hajdú, 1964). It is felt that furosemide exerts its action through depletion of sodium chloride.

\section{SUMMARY}

A significant reduction in the histamine-stimulated gastric acid output was observed with a low-salt diet alone or in combination with the diuretic furosemide in 16 out of 18 subjects. This observation may afford a new approach in the management of peptic ulcer.

\section{REFERENCES}

Barreras, R. F., and Donaldson, R. M., Jr (1967). Role of calcium in gastric hypersecretion, parathyroid adenoma and peptic ulcer. New Engl. J. Mfd., 276, 1122-1124.

Binnion, P. F., Davis, J. O., Brown, T. C., and Olichney, M. J. (1965) Mechanisms regulating aldosterone secretion during sodium depletion. Amer. J. Physiol., 208, 655-661.

Bledsoe, T., Island, D. P., and Liddle, G. W. (1966). Studies of the mechanism through which sodium depletion increases aldosterone biosynthesis in man. J. clin. Invest., 45, 524-530.

Cade, R., and Perenich, T. (1965). Secretion of aldosterone by rats Amer. J. Physiol., 208, 1026-1030.

Crabbé, J., Reddy, W. J., Ross, E. J., and Thorn, G. W. (1958). The role of the adrenal cortex in the normal adaptation to dietary sodium deprivation. J. clin. Endocr., 18, 1147-1158.
Desai, H. G., Borkar, A. V., and Jeejeebhoy, K. N. (1967). Doseweight relationship of histamine for maximal stimulation of gastric acid secretion. Gastroenterology, 53, 712-718.

Hightower, N. G. (1966). Gastric secretion. In the Physiological Basis of Medical Practice. Edited by C. H. Best and N. B. Taylor, p. 1091. Williams and Wilkins, Baltimore.

Johnston, I. D. A. (1965). Reduction of gastric acid secretion without operation. In Recent Advances in Gastroenterology. Edited by J. Badenoch and B. N. Brooke pp. 107-115. Churchill, London.

Kay, A. W. (1953). Effect of large doses of histamine on gastric secretion of hydrochloride acid: an augmented histamine test. Brit. med. J., 2, 77-80.

Kramer, P., and Markarian, B. (1959). The effect of chlorothiazide on human gastric secretion. Amer. J. dig. Dis., 4, 130-136.

Lahiri, S. C. (1953). Gastric hydrochloric acid and blood chloride. J. Indian med. Ass., 22, 235-240.

Lawrie, J. H., Smith, G. M. R., and Forrest, A. P. M. (1964). The histamine-infusion test. Lancet, 2, 270-273.

- and Forrest, A. P. M. (1965). The measurement of gastric acid. Postgrad. med. J., 41, 408-417.

Leutscher, J. A., Jr., and Axelrad, B. J. (1954). Increased aldosterone output during sodium deprivation in normal men. Proc. Soc. exp. Biol. (N.Y.), 87, 650-653.

Lindner, A. E., Cohen, N., Dreiling, D. A., and Janowitz, H. D. (1962). Effect of acetazolamide on secretion of sodium and potassium by the human stomach. J. appl. Physiol., 17, 514-518.

Muschaweck, R., and Hajdú, P. (1964). Die salidiuretische Wirksamkeit der Chlor-N-(2-furylmethyl(-5-sulfamanthranilsäure. Arzneimittel-Forsch., 14, 44-47.

Ojha, K. N., and Ahmed, Q. (1967). The inhibitory effect of some thiazine diuretics and acetazolamide on the histamine induced gastric secretory response in pigeons. Ind.J. Physiol.Pharmacol., 11, 53-61.

Robson, A. O., Kerr, D. N. S., Aschcroft, R., and Teasdale, C. (1964). The diuretic response to furosemide. Lancet, 2, 1085 1088.

Taylor, N. B. (1955). Gastric digestion. In The Physiological Basis on Medical Practice. 6th ed., Edited by C. H. Best and N. B. Taylor, p. 499. Williams and Wilkins, Baltimore.

Van Buchem, F. S. P., Doorenbos, H., and Elings, H. S. (1956). Conn's syndrome caused by adrenocortical hyperplasia. Acta endocr. (Kbh.), 23, 313-330. 